\title{
Keunikan Wacana Qur’ani dalam Penggunaan Bilangan
}

\author{
Mat Taib Pa \\ Universiti Malaya, mattaib@um.edu.my \\ Mohd Zaki Abd Rahman \\ Universiti Malaya,mzakirah@um.edu.my \\ Mohamad Hussin \\ Universiti Malaya, mohamadhussin@um.edu.my \\ DOI: https://doi.org/10.22452/usuluddin.vol47no2.2
}

\begin{abstract}
Abstrak
Makalah ini membincangkan mengenai keunikan wacana Qur'ani dari sudut penggunaan bilangan. Hal ini adalah penting untuk dibincangkan kerana penggunaan bilangan dalam al-Quran al-Karim adalah unik dan kadang-kadang agak berbeza atau tidak selari dengan kaedah dan rumus biasa nahu bahasa Arab. Keunikan ini memberi kesan kepada makna dan maksud yang ingin disampaikan secara tidak langsung tetapi mempunyai maksud tersirat dan pengajaran tertentu. Kajian ini mendapati bahawa bilangan dalam al-Quran al-Karim digunakan dengan dua maksud umum. Pertamanya maksud bilangan berkenaan sama ada secara langsung atau tidak langsung yang dilihat dari aspek dan konteks tertentu yang difokuskan. Keduanya maksud balaghah tertentu, seperti sedikit, kecil, besar, kehinaan, keagungan, penghormatan, melebih-lebihkan, personal, baik, buruk dan sebagainya.
\end{abstract}

Kata kunci: wacana Qur'ani, bilangan, nahu Bahasa Arab

\section{The Uniqueness of the Qur'anic Discourse in the Use of Multiplier}

\begin{abstract}
This paper discusses the uniqueness of the Qur'anic discourse in the use of multiplier. It is pertinent to discuss this as the use of numbers in the alQuran al-Karim is unique and sometimes distinctive from or inconsistent with its conventional use in Arabic grammar. This uniqueness indirectly affects the conveyance of meanings, but well-intended for hidden meanings and teaching of values. This study has found that multipliers in the al-Quran al-Karim are used for two general purposes. Firstly, in carrying quantifying meaning either directly or indirectly based on the aspect and context of its usage. Secondly, in carrying rhetorical meaning such as little, small, big, humiliation, grandeur, honor, exaggeration, personal, good, bad and so on.
\end{abstract}

Keywords: Qur'anic discourse, multiplier, Arabic grammar 


\section{Pendahuluan}

Al-Quran al-Karim merupakan sebuah kitab yang diturunkan oleh Allah SWT dalam bahasa Arab. Ia merupakan kitab mukjizat dari semua aspeknya sama ada bahasa mahu pun isi kandungannya. Antara aspek-aspek ini, aspek yang paling terunggul ialah aspek bahasanya yang amat halus, seni dan unik. Ia mempunyai kehalusan dan keseniannya yang tersendiri sehingga tidak mampu ditandingi bukan sahaja di zaman dahulu malah sampai hari Kiamat.

Keunikan bahasa al-Quran al-Karim terjelma dalam semua aspek bahasa, antaranya yang penting ialah aspek bilangan nahuan. Dalam bahasa Arab bilangan nahuan mempunyai tiga jenis, iaitu mufrad, duaan dan jamak. Penggunaan jenis-jenis ini dalam al-Quran al-Karim adalah sangat unik. Ulama telah menganalisis penggunaannya dalam ayat-ayat al-Quran al-Karim dalam kadar yang banyak, namun mengikut pemerhatian penulis mereka kurang membincangkannya secara khusus dan terperinci.

\section{Penggunaan Bilangan dalam Konteks Metode Iltizam}

Perkara pertama yang menarik perhatian dan perlu dibincangkan ialah satu fenomena khas bahasa dalam al-Quran al-Karim yang diperhatikan oleh ulama dan disebut sebagai metode iltizam atau konsisten. Ia bermaksud "membezakan antara perkataan-perkataan secara terperinci dan menggunakan setiap perkataan dengan satu bentuk khusus sahaja, di samping menggunakan perkataan bandingannya juga tanpa campur aduk antara penggunaan keduadua perkataan". ${ }^{1}$ Antara bentuk metode konsisten dalam konteks ini ialah: ${ }^{2}$

A. Penggunaan perkataan tertentu dalam bentuk mufrad sahaja dalam al-Quran al-Karim seperti perkataan al-șadīq, alnahār, al-sam', al-ard, al-nār, al-nūr. Apa yang menariknya ialah sekiranya dikehendaki maksud jamak maka tidak digunakan bentuk-bentuk jamak yang diketahui, tetapi digunakan cara lain

1 'Abd al-'Aẓīm Ibrāhīm Muḥammad al-Muț'in̄̄, Khașā'is al-Ta'bīr alQurāniyy wa Simātuhu al-Balāghiyyah (Kaherah: Maktabah Wahbah, 1992), $1: 278$.

2 'Abd al-'Aẓ̄m, Khașā'is al-Ta'bīr al-Qurāniyy, 2: 314-315; 'Abd al-Fattāḥ Fayyūd, Min Balāghah al-Nażm al-Qur'āniyy (Kaherah: Mațba'ah al-Husayn al-Islāmiyyah, t.t.), 22. 
seperti perkataan al-ard yang apabila dikehendaki makna jamak maka digunakan ungkapan wa min al-ard mithlahunn dalam ayat berikut:

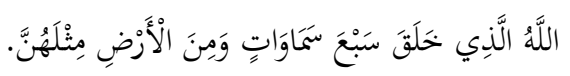

Al-Ṭalāq 65:12

Terjemahan: Allah jualah yang menciptakan tujuh petala langit dan bumi juga seperti itu.

Kadang-kadang digunakan perkataan lain seperti perkataan al-nahār yang apabila dikehendaki maksud jamaknya maka digunakan perkataan ayyām dalam ayat berikut:

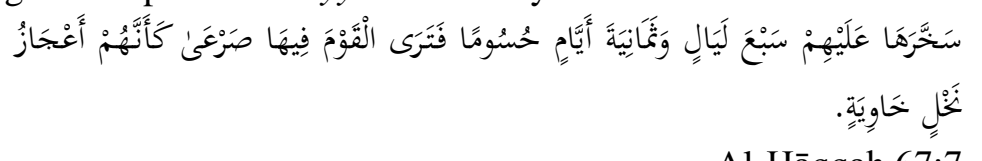

Al-Hāqqah 67:7

Terjemahan: Dia menjadikannya menimpa mereka tujuh malam lapan hari terus-menerus, maka engkau melihat kaum itu bergelimpangan mati, seolah-olah mereka merupakan batang-batang pohon kurma yang lompang.

B. Penggunaan perkataan tertentu dalam bentuk jamak sahaja dalam al-Quran al-Karim seperti perkataan al-zulumāt, al-albāb, al-arj $\bar{a}$ '. Apa yang menariknya juga ialah apabila dikehendaki bentuk mufrad maka digunakan perkataan lain seperti perkataan al-albāb yang apabila dikehendaki bentuk mufradnya maka digunakan perkataan al-qalb dan al-fu' $\bar{a} d .^{3}$ Kenyataan penggunaan perkataan al-albāb dalam bentuk jamak sahaja memang benar. Namun, kenyataan bahawa apabila dikehendaki bentuk mufrad maka digunakan perkataan al-qalb dan $a l-f u$ 'a $d$, agak sukar untuk diterima kerana sebenarnya terdapat perbezaan antara ketiga-tiga perkataan tersebut kerana hakikatnya tiada sinonim dalam alQuran al-Karim.

Persoalannya ialah kenapa sesuatu perkataan itu digunakan dalam satu bentuk sahaja sama ada mufrad atau jamak dalam alQuran al-Karim? Ulama telah membincangkan perkara ini dan memberi pelbagai sebab alasan. Bagi penggunaan bentuk mufrad sahaja dalam al-Quran al-Karim, secara amnya terdapat tiga sebab umum yang diutarakan, iaitu:

3 'Abd al-Fattāḥ Fayyūd, Min Balāghat al-Nażm al-Qur'āniyy, 22. 
1. Sebab berkaitan sebutan dan bunyi.

Antara sebab yang diberikan untuk penggunaan bentuk mufrad sahaja adalah sekiranya dijamakkan sebutannya akan menjadi susah dan berat. Contohnya perkataan al-ard yang sebutan jamaknya adalah berat, iaitu $\bar{a} r u d$, a $r \bar{a} d$, urū ${ }^{4}{ }^{4}$ Alasan yang diberikan ini pada dasarnya boleh diterima, kerana bunyi perkataan-perkataan ini memang agak berat. Namun, sebenarnya terdapat bentuk jamak lain yang sebutannya agak ringan dan digunakan pada hari ini, iaitu al-arāộ̀.

2. Sebab nahuan.

Sebahagian ulama berpendapat bahawa perkataan al-sam ' hanya disebut dalam bentuk mufrad sahaja kerana ia merupakan mașdar. Hal ini adalah kerana mașdar dalam bahasa Arab tidak boleh dijamakkan. ${ }^{5}$ Mengikut al-Suhaylī perkataan al-ard juga tidak boleh dijamakkan kerana ia menyerupai mașdar seperti perkataan al-taht, al-sufl. Sebagaimana kedua-duanya tidak boleh dijamakkan maka perkataan al-ard juga tidak boleh dijamakkan. ${ }^{6}$

3. Sebab berkaitan makna.

Dalam konteks ini, terdapat beberapa sebab yang diketengahkan oleh ulama dan ahli bahasa. Pertamanya ialah penggunaan bentuk mufrad sahaja adalah untuk menunjukkan maksud tunggal atau satu sahaja kerana maksud bilangan dua atau banyak tidak berkaitan dengan perkara tersebut. Contohnya ialah penggunaan perkataan $\mathrm{al}$-sam ' dalam bentuk mufrad sahaja adalah kerana tiada pilihan dalam proses penerimaan pendengaran ${ }^{7}$ dan objek yang didengar hanya satu sahaja, iaitu suara. ${ }^{8}$

Di samping itu, ulama juga turut menyatakan makna lain selain maksud bilangan mufrad seperti perkataan al-ard yang mengikut Ibn al-Qayyim ia merupakan tempat dunia dan nilainya adalah sedikit atau kecil apabila dibandingkan dengan akhirat. Allah SWT tidak menyebutnya kecuali dalam konteks kekerdilan dan kehinaan. Hal ini adalah kerana jamak menunjukkan

4 Muḥammad bin Abī Bakr Ibn al-Qayȳ̄m, Badā' '̄ 'al-Fawā'id (Beirut: Dār alKitāb al-'Arabiyy, t.t.), 1: 115.

5 Jalāl al-Dīn al-Suyūṭị, Al-Itqān fì 'Ulūm al-Qur'ān (Beirut: al-Maktabah alThaqāfiyyah, 1973), 2:301.

6 Abū al-Qāsim 'Abd al-Rahmān al-Suhailiyy, Natā'ij al-Fikr fì al-Naḥw (Riyadh: Dār al-Riyāḍ li al-Nashr wa al-Tawzī', t.t.), 157-160.

7 Al-Suyūṭi, Al-Itqān fì 'Ulūm al-Qur'ān, 1:115.

8 Al-Suyūṭi, Al-Itqān fì 'Ulūm al-Qur'ān, 2:301. 
kebesaran dan keagungan ${ }^{9}$ Pendapat yang hampir sama diberikan oleh al-Suhaylī yang menyatakan:

"Perkataan al-ard tidak disebut dalam al-Quran dengan maksud zatnya atau menyatakan hakikatnya, sebaliknya dengan maksud bahagian bawah sebagai peringatan daripada Allah SWT tentang kehinaannya dan sebagai sesuatu yang tidak perlu diingat serta diambil berat kerana ia merupakan tempat kehidupan dunia". ${ }^{10}$

Daripada sini diperhatikan bahawa sebab penggunaan bentuk mufrad adalah untuk menunjukkan kekerdilan, kurang bernilai dan seumpamanya dan ia tiada kaitan dengan bilangan, tetapi dilihat dari sudut lain yang disebut sebagai maksud atau tujuan balaghah.

Kesimpulannya dalam konteks makna ini, boleh dibahagikan kepada dua. Pertama maksud hakiki/ leksikologi, iaitu mufrad dan keduanya maksud balaghah, iaitu kekerdilan, kurang bernilai dan seumpamanya.

Berhubung dengan penggunaan perkataan tertentu dalam bentuk jamak sahaja pula, beberapa sebab dan alasan telah diberikan oleh ulama dan ahli bahasa, antaranya:

i. Sebab berkaitan bunyi dan sebutan.

Antara sebab yang diberikan untuk penggunaan bentuk jamak sahaja ialah sebutannya ringan dan sekiranya dimufradkan sebutannya akan menjadi berat dan susah. Untuk perkataan alalbāb umpamanya menurut Ibn al-Athīr alasan penggunaannya dalam bentuk jamak sahaja adalah kerana "perkataan ini ringan untuk disebut dan makhrajnya berjauhan" Ada pula yang membandingkannya dengan bentuk mufradnya, iaitu $a l-l a b b$ yang sebutannya adalah berat ${ }^{12}$ Alasan yang diberikan ini pada dasarnya adalah logik dan boleh diterima kerana memang sebutan al-labb agak sukar berbanding dengan sebutan al-albāb.

ii. Sebab berkaitan makna.

Contohnya ialah perkataan al-zulumāt yang digunakan dalam bentuk jamak sahaja kerana ia merujuk kepada kebatilan, kesesatan, kekufuran dan sebagainya yang sememangnya banyak

9 Ibn al-Qayyim, Badā' '`‘ al-Fawā’id, 1: 114-117.

10 Al-Suhailiyy, Natā' $i j$ al-Fikr fi al-Nahww, 157-160.

11 Diyā' al-Dīn Ibn al-Athīr, Al-Mathal al-Sā'ir fì Adāb al-Kātib (Kaherah: Mațba'ah al-Bābiyy al-Halabiyy, 1990), 1:384.

12 'Abd al-Fattāḥ Fayyūd, Min Balāghah al-Nażm al-Qur'āniyy, 28. 
sama ada dilihat dari sudut bentuk, sumber atau sebagainya ${ }^{13}$ Alasan ini ada kebenarannya khususnya jika dilihat kepada realiti semasa dan perkembangan zaman yang menyaksikan semakin hari semakin banyak kejahatan, berbanding dengan kebaikan.

Dalam konteks ini, sebagai contoh penggunaan metode iltizam bagi kedua-dua bentuk mufrad dan jamak, penulis ingin menganalisis penggunaan perkataan al-zulumāt dengan al-nūr yang digandingkan bersama dalam satu konteks ayat. Hal ini berulang sebanyak 12 kali dalam al-Quran al-Karim. ${ }^{14}$ Antara ayat tersebut ialah ayat berikut:

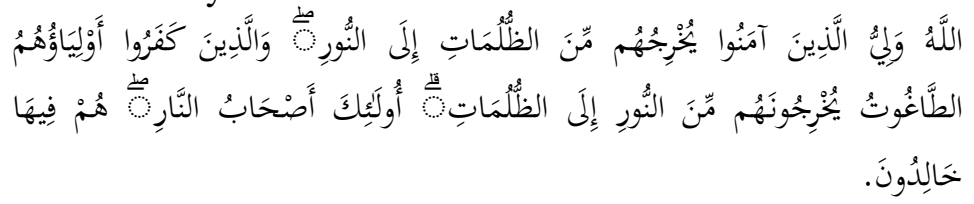

Al-Baqarah 2:257

Terjemahan: Allah jualah pelindung orang-orang yang beriman. Dia mengeluarkan mereka dari kegelapan kepada cahaya. Manakala orang-orang kafir pula, pelindungpelindung mereka ialah syaitan yang mengeluarkan mereka daripada cahaya kepada kegelapan.

Terdapat beberapa pendapat dalam mentafsirkan penggunaan bentuk mufrad dan jamak ini. Ibn al-Qayyīm berpendapat sebabnya ialah:

"Jalan kebenaran itu hanya satu sahaja kerana sumbernya ialah Allah, Raja Yang Sebenar. Sementara jalan kebatilan itu banyak dan pelbagai kerana ia tidak merujuk kepada satu perkara dan tujuan yang boleh dicapai, malah ia ibarat cabang-cabang jalan, sedangkan jalan kebenaran ibarat jalan yang boleh menyampaikan kepada tujuan yang sekali pun ia pelbagai, namun sumbernya ialah satu jalan sahaja". ${ }^{15}$

Diperhatikan bahawa alasan yang digunakan ialah maksud bilangan itu sendiri. Namun, ada yang mentafsirkannya dari sudut maksud balaghah seperti al-Alūsī yang menyatakan bahawa "kegelapan itu walaupun sedikit ia dianggap banyak, sebaliknya

13 Ibn al-Qayyim, , Badā' '̄' al-Fawā'id, 1:119; 'Abd al-'Az̄ìm, Khașā'is alTa 'bōr al-Qurāniyy wa Simātuhu al-Balāghiyyah, 2:396-397.

14 Muhammad al-Amīn Al-Khuḍrī, al-I'jāz al-Bayāniyy fì Șiyagh al-Alfāz (Kaherah: Maṭba'ah al-Husayn al-Islāmiyyah, 1993), 34.

15 Ibn al-Qayyim, Badā' '̄' al-Fawà'id, 1:119. 
cahaya walaupun banyak ia dianggap sedikit selama mana ia tidak memudaratkan"16 Begitu juga dengan Ibn Kathīr yang berpendapat perkataan al-nūr dimufradkan kerana ia lebih mulia. ${ }^{17}$

Diperhatikan bahawa mengikut pendapat pertama penggunaan bentuk mufrad dan jamak memang merujuk kepada bilangan berkenaan. Manakala mengikut pendapat kedua pula penggunaan bentuk mufrad merujuk kepada maksud balaghah, iaitu kemulian. Antara kedua-dua pendapat ini nampaknya pendapat pertama lebih kuat kerana ia lebih rasional apabila dikaitkan isu ini dengan bilangan, sementara pendapat kedua tidak mempunyai alasan yang kukuh untuk mengatakan bahawa bentuk mufrad lebih mulia.

Kesimpulannya, dalam konteks metode iltizam, selain daripada sebab berkaitan sebutan dan nahuan, mufrad dan jamak digunakan untuk dua maksud, pertamanya maksud hakiki, iaitu bilangan masing-masing dan keduanya maksud balaghah seperti kekerdilan dan kehinaan.

\section{Penggunaan Bilangan dalam Konteks Bukan Metode Iltizam}

Dalam konteks bukan metode iltizam pula, persoalan yang ingin dibincangkan ialah apakah bentuk-bentuk bilangan itu digunakan dengan maksud bilangan tersebut atau maksud lain juga?

A. Maksud bilangan hakiki.

Pada dasar dan logiknya, bentuk bilangan nahuan memang digunakan untuk menunjukkan bilangan tersebut kerana itulah tujuan asal dibina pelbagai bentuk bilangan berkenaan. Sebagai contohnya ialah penggunaan perkataan al-sirāt dan al-subul dalam ayat berikut:

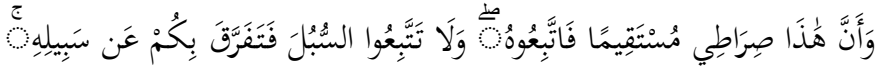

$$
\text { Al-'An'ām 6:153 }
$$

Terjemahan: Bahawasanya inilah jalan-Ku yang lurus, maka ikutilahnya dan janganlah kamu mengikuti jalan-jalan lain, maka ia akan memecahbelahkan kamu dari jalannya.

Dalam ayat di atas, perkataan al-șirăt yang dikaitkan dengan jalan yang lurus disebut dalam bentuk mufrad dan al-subul yang

16 Shihāb al-Dīn al-Sayyid Maḥmūd al-Alūsī, Rūh al-Ma 'ānī fì Tafsìr al-Qur'ān wa al-Sab 'al-Mathānī (Beirut: Dār Ihyyā’ al-Turāth al-'Arabiyy, t.t.), 1:197.

17 Ismā'īl Ibn 'Umar Ibn Kathīr, Tafsì̀r al-Qur'ān al-'Aẓ̄m (Beirut: Dār Ibn Hazm, 2000), 2:123 
dikaitkan dengan jalan yang tidak lurus disebut dalam bentuk jamak. Ibn al-Qayyīm berpendapat sebabnya ialah jalan kebenaran itu hanyalah satu sahaja, manakala jalan kebatilan adalah banyak dan pelbagai. ${ }^{18}$ Pendapat ini ada kebenarannya kerana Ibn Mas'ūd meriwayatkan bahawa pada satu ketika Rasulullah SAW telah membuat satu garisan dengan tangan Baginda kemudian bersabda: "Ini adalah jalan Allah Taala yang lurus". Kemudian Baginda membuat beberapa garisan di sebelah kanan dan kiri garisan tersebut, kemudian Baginda bersabda: "Tiada satu jalan pun daripada jalan-jalan ini kecuali terdapat padanya syaitan yang menyeru kepadanya". Kemudian Baginda membaca ayat wa anna hâdhā șirāṭ̂ mustaqīma.$^{19}$ Ini menjelaskan bahawa penggunaan mufrad dan jamak memang menunjukkan maksud bilangan yang berkenaan.

Begitu juga dengan ayat berikut:

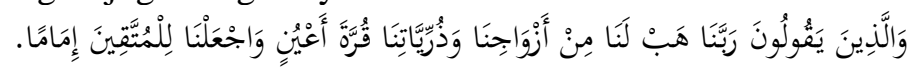

Al-Furqān 25:74

Terjemahan: Orang-orang yang berkata: "Wahai Tuhan kami, anugerahkanlah kepada kami isteri-isteri dan keturunan kami sebagai penyejuk mata dan jadikanlah kami imam bagi orangorang yang bertakwa."

Ganti nama $n \bar{a}$ yang digunakan ialah jamak, tetapi rujukannya imāmā ialah mufrad. Sebabnya ialah orang-orang bertaqwa mempunyai satu kepimpinan, tujuan dan petunjuk yang menunjukkan kesatuan seruan kebenaran. ${ }^{20}$ Diperhatikan bahawa bentuk bilangan di sini menunjukkan bilangan yang berkenaan.

Sehubungan dengan itu, didapati juga penggunaan bilangan nahuan memang menunjukkan bilangan berkenaan tetapi secara tidak langsung yang dilihat dari aspek dan konteks tertentu yang difokuskan. Sebagai contohnya ialah perkataan al-mashriq, almaghrib seperti dalam ayat berikut:

18 Ibn al-Qayyim, Badā' '̄' al-Fawā'id, 1:119.

19 Al-Alūsī, Rūh al-Ma 'ānī fì Tafsīr al-Qur'ān wa al-Sab 'al-Mathānī, 8:57.

20 Al-Khuḍ̂ī, al-I 'jāz al-Bayāniyy fì Șiyagh al-Alfāz, 42. 


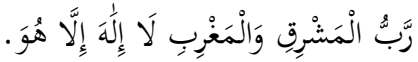

Al-Muzammil 73:9

Terjemahan: (Dialah) Tuhan tempat timbul dan tenggelam matahari, tiada Tuhan melainkan Dia.

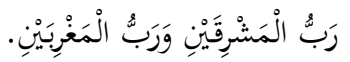

Al-Raḥman 55:17

Terjemahan: (Dialah) Tuhan kedua-dua timur dan kedua-dua barat.

$$
\text { فَلَا أُقْسِمْ بِربِّ الْمَشَارِقِ وَالْمَغَارِبِ. }
$$

Al-Ma'ārij 70:40

Terjemahan: Aku bersumpah dengan Tuhan semua arah timur dan barat.

Ulama menyatakan bahawa digunakan kedua-dua perkataan ini dalam bentuk yang berlainan disebabkan konteks dan maksudnya adalah berlainan. Konteks ayat pertama ialah perbezaan siang dan malam yang berkaitan dengan matahari. Oleh itu, yang dimaksudkan dengan al-mashriq, al-maghrib di sini ialah tempat timbul dan tenggelamnya matahari secara umum.

Sementara konteks ayat kedua pula ialah dualism, iaitu kejadian dan pengajaran, matahari dan bulan, bintang dan tumbuhan, langit dan bumi, keadilan dan kezaliman, bijian dan buah-buahan, manusia dan jin, kemudian diikuti dengan dua perkataan ini al-mashriqayn, al-maghribayn dengan maksud dua tempat timbul dan tenggelam matahari pada musim panas dan musim sejuk.

Ayat ketiga pula membicarakan tentang keluasan rububiyyah dan kekuasaan Allah SWT. Oleh itu, menyebut bilangan yang banyak adalah sesuai dengan konteks ayat. Maka yang dimaksudkan dengan al-mashāriq, al-maghārib ialah perubahan tempat serta masa timbul dan tenggelam matahari setiap hari yang merupakan salah satu tanda kekuasaan dan kebesaran Allah SWT. $^{21}$

${ }^{21}$ Ibn al-Qayyim, Badā' '`‘ al-Fawā'id, 1:121; Jalāl al-Dīn al-Suyūṭī, Mu'tarak al-Aqrān fì I'jāz al-Qur'ān (Beirut: Dār al-Fikr al-'Arabiyy, t.t.), 3:598; Muḥammad Ibn 'Abd Allāh al-Zarkashī, Al-Burhān fì 'Ulūm al-Qur'ān (Kaherah: Dār Ihyā' al-Kutub al-'Arabiyyah, 1957), 4:15, Al-Suyūṭi, Al-Itqān fì 'Ulūm al-Qur'ān, 1:194. 
Al-Sha'rāwī pula melihat dari sudut lain. Mengikutnya kedua-dua perkataan ini disebut dalam bentuk mufrad al-mashriq, al-maghrib kerana bumi ini secara amnya mempunyai timur dan baratnya. Ia disebut dalam bentuk duaan al-mashriqayn, almaghribayn pula kerana bumi ini dari sudut cahaya terbahagi kepada dua bahagian, iaitu bahagian yang terang kerana menerima cahaya matahari dan bahagian yang gelap kerana tidak menerima cahaya matahari. Setiap bahagian ini juga mempunyai timur dan barat masing-masing yang secara keseluruhannya menjadikan bumi ini mempunyai dua timur dan dua barat. Ia disebut pula dalam bentuk jamak al-mashāriq, al-maghārib kerana mengikut ilmu falak moden setiap negara mempunyai timur dan barat masing-masing yang secara keseluruhannya menjadikan bumi ini mempunyai banyak timur dan barat. ${ }^{22}$

Kedua-dua pendapat ini sebenarnya bukanlah merupakan perbezaan, tetapi lebih merupakan kepelbagaian, walaupun pendapat kedua nampaknya bersifat saintifik. Kesimpulannya bilangan yang disebut menunjukkan kepada bilangan yang berkenaan, namun ia berkaitan dengan konteks ayat dan sudut pandang tertentu.

Perkara yang sama dapat diperhatikan pada perkataan sama yang digunakan dalam bentuk bilangan yang berlainan. Contohnya ialah perkataan $\bar{a} y a h$ dan $\bar{a} y \bar{a} t$ yang disebut dalam ayat berikut:

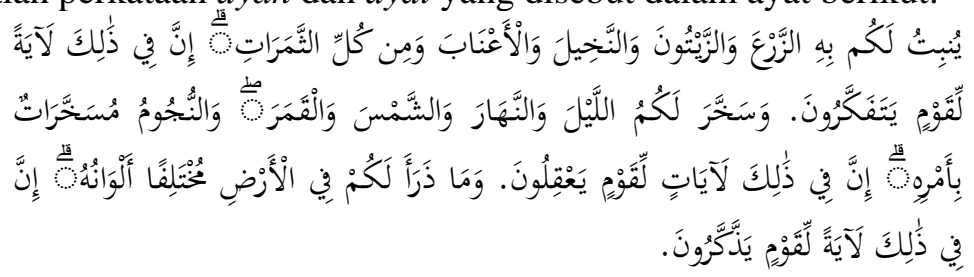

Al-Nahl 16:11-13

Terjemahan: Dialah yang menumbuhkan juga bagi kamu dengan air hujan itu tanam-tanaman, zaitun, kurma, anggur dan segala macam buah-buahan. Sesungguhnya pada yang demikian itu benar-benar terdapat tanda (kekuasaan Allah) bagi kaum yang berfikir. Dia juga telah menundukkan bagimu malam dan siang serta matahari dan bulan. Begitu juga bintang-bintang ditundukkan dengan perintah-Nya.

${ }^{22}$ Muhammad Mutawallī al-Sha'rāwī, 'Alā Mā'idah al-Fikr al-Islāmī (t.tp.: Dār al-'Awdah, t.t.), 23-24. 
Sesungguhnya pada yang demikian itu benar-benar terdapat tanda-tanda (kekuasaan Allah) bagi orang-orang yang beraka (Dia juga menundukkan) apa yang diciptakan-Nya untuk kamu di bumi ini dengan kepelbagaian jenisnya. Sesungguhnya pada yang demikian itu benar-benar terdapat tanda (kekuasaan Allah) bagi orang-orang yang mengambil peringatan.

Dalam ayat pertama digunakan āyah dalam bentuk mufrad kerana tumbuhan-tumbuhan yang disebutkan itu walaupun banyak, namun semuanya berasal dari satu sumber, iaitu air yang turun dari langit lalu menyuburkannya dan mengeluarkan pelbagai buah-buahan. Dalam ayat kedua pula disebut berbagai-bagai fenomena alam: malam, siang, matahari dan bulan yang semuanya merupakan tanda-tanda kebesaran Allah SWT yang banyak, lebihlebih lagi ia sesuai dengan perkataan musakhkharāt yang disebut dalam bentuk jamak. Sementara ayat ketiga pula, diterangkan sumber yang satu juga, iaitu bumi. ${ }^{23}$

Diperhatikan bahawa penggunaan bentuk mufrad dan jamak di sini adalah berkaitan dengan perkara yang difokuskan. Sekiranya yang difokuskan itu satu, maka digunakan bentuk mufrad, seolah-olahnya Allah SWT ingin menarik perhatian pembaca kepada hubungan antara satu sumber yang difokuskan dengan benda-benda lain yang disebut. Sekiranya apa yang difokuskan itu adalah banyak, maka digunakan bentuk jamak seolah-olahnya setiap satu itu perlu diberi penekanan yang khusus kerana kehalusan dan kehebatannya. Kesimpulannya ialah bentuk mufrad dan jamak memang menunjukkan bilangannya, namun ia dilihat dari sudut kaitannya dengan perkara yang difokuskan.

Begitu juga dengan perkataan al-samā', al-samāwāt seperti dalam ayat berikut:

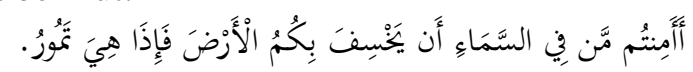

Al-Mulk 67:16

Terjemahan: Apakah kamu merasa aman terhadap Allah di langit bahawa Dia akan menenggelamkan bumi bersama kamu, sehingga tiba-tiba bumi itu bergoncang?

23 Al-Zarkashī, Al-Burhān fì 'Ulūm al-Qur'ān, 4:14; Al-Khațīb al-Iskāfiyy, Durrah al-Tanzīl wa Ghurrah al-Ta'wìl fì Bayān al-Āyāt al-Mutashābihāt (Beirut: Dār al-Āfāq al-Jadīdah, 1977), 252. 


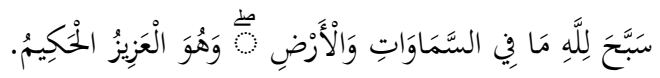

Al-Hadīd 57:1

Terjemahan: Segala yang ada di langit dan di bumi mengucap tasbih kepada Allah dan Dialah Yang Maha Perkasa, lagi Maha Bijaksana

Ibn al-Qayyim berpendapat sekiranya dimaksudkan dengan langit itu berdasarkan konteks ayat ialah sifat tinggi, atas atau arah, maka digunakan bentuk mufrad dan sekiranya dimaksudkan dengannya ialah langit itu sendiri yang banyak, maka digunakan bentuk jamak yang menunjukkan keagungan dan kekuasaan. ${ }^{24}$ Justeru, mufrad menunjukkan makna satu, tetapi bukan merujuk kepada hakikat langit itu sendiri, sebaliknya kepada maksud yang berkaitan dengannya, iaitu arah atau ketinggian.

Pendapat ini boleh diterima, cuma penulis ingin menambah bahawa penggunaan bentuk mufrad ini sesuai dengan fokus ayat pertama, iaitu Allah SWT sendiri yang Esa dan ia juga mengandungi unsur mushākalah atau persamaan bentuk dengan perkataan "bumi" serta konteks umum ayat ini juga ialah mufrad. Sementara penggunaan jamak memang menunjukkan kepada bilangan banyak yang sesuai dengan konteks ayat. Kesimpulannya penggunaan mufrad dilihat dari sudut makna tidak langsung dan kesesuaian konteks ayat, sementara jamak pula adalah dari sudut hakiki.

Walaupun alasan ini sesuai dengan ayat berkenaan, namun ia seolah-olah kurang sesuai digunakan untuk ayat 31 surah Yūnus dan ayat 24 surah Sabā':

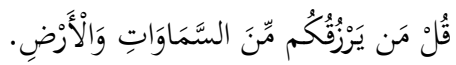

Yunus 10:31; Sabā' 34:24

Terjemahan: Katakanlah: "Siapakah yang memberi rezeki kepadamu dari langit dan bumi?

Ini adalah kerana perkataan al-samā' digunakan dalam bentuk mufrad dalam ayat pertama dan dalam bentuk jamak dalam ayat kedua, sedangkan konteks kedua-dua ayat tersebut adalah sama, iaitu pemberian rezeki. Jadi, apakah alasan penggunaan mufrad dan jamak di sini? Mengikut Ibn al-Qayyīm sebabnya di

${ }^{24}$ Ibn al-Qayyīm, Badā'̄̄ al-Fawā'id, 1:115; Muhammad bin Abī Bakr Ibn alQayyīm, al-Tafsìr al-Qayyīm (t.tp.: Matba'ah al-Sunnah al-Muhāmmadiyyah, 1949), 305. 
sini ialah perkataan al-sam $\bar{a}$ ' dimufradkan dalam ayat pertama kerana penerimanya mengakui dan menerima hakikat rezeki dari Allah SWT, tetapi dalam ayat kedua ia dijamakkan kerana penerimanya tidak mengaku perkara itu, lalu Allah SWT memerintahkan Nabi supaya menjawab bahawa Dia menurunkan rezeki yang banyak dengan kepelbagaian jenisnya dari langit yang tujuh. ${ }^{25}$ Oleh itu, konteks ayat kedua memerlukan penggunaan bentuk jamak berbanding dengan ayat pertama.

Penulis ingin menambah bahawa secara hakikatnya memang rezeki yang diturunkan Allah SWT adalah pelbagai dari sumber yang banyak. Oleh itu, penggunaan jamak dalam ayat kedua adalah secara hakiki yang menunjukkan kepada bilangan yang banyak dan sesuai dengan konteks penerima. Namun dalam ayat pertama, persoalan yang masih timbul apakah tidak boleh digunakan bentuk jamak juga? Penulis berpendapat pada dasarnya tidak menjadi sesuatu kesalahan sekiranya digunakan bentuk jamak di sini, tetapi al-Quran menggunakan juga bentuk mufrad kerana situasi penerima tidak memerlukan penggunaan bentuk jamak dan memadai digunakan bentuk mufrad sahaja, lagikan pula cara begini menunjukkan perbezaan yang nyata antara orang yang beriman dan tidak beriman. Oleh itu, penggunaan mufrad tidak merujuk kepada bilangan, tetapi sekiranya digunakan jamak ia merupakan suatu kelewahan. Ini menunjukkan bahawa al-Quran al-Karim menggunakan setiap perkataan tepat dengan konteksnya tanpa sedikit pun kekurangan dan kelewahan.

B. Maksud balaghah.

Analisis contoh-contoh lepas menunjukkan bentuk bilangan digunakan dengan maksud asal bilangan berkenaan. Walau bagaimanapun, kadang-kadang bentuk bilangan digunakan dengan maksud lain yang disebut sebagai maksud balaghah. Antaranya ialah maksud kadar sedikit seperti dalam ayat berikut:

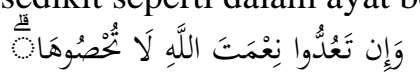

Ibrāhīm 14:34

Terjemahan: Jika kamu menghitung nikmat Allah, kamu tidak akan dapat.

Perkataan ni'mah disebut dalam bentuk mufrad untuk memberi maksud bahawa sedikit sahaja nikmat Allah SWT tidak

25 Ibn Qayyīm, Badā'ì' al-Fawā'id, 117. 
terkira nilainya, apatah lagi sekiranya ia banyak. ${ }^{26}$ Diperhatikan di sini bahawa bentuk mufrad tidak memberi maksud satu, tetapi makna sedikit.

Antara maksud balaghah di sebalik bentuk bilangan ialah maksud kecil atau besar seperti perkataan al-țfl, al-atfâl dalam ayat berikut:

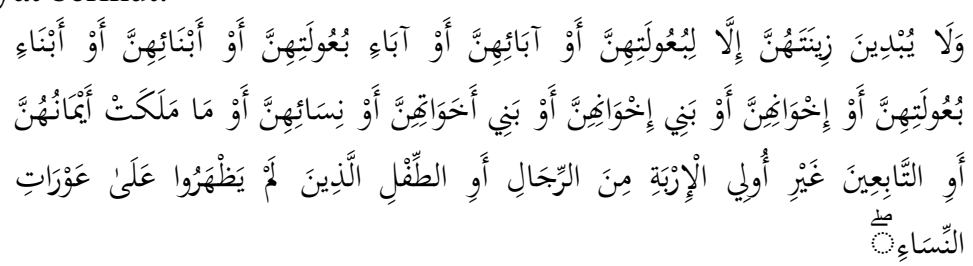

Al-Nūr 24:31

Terjemahan: Janganlah mereka menampakkan perhiasannya kecuali kepada suami mereka, ayah mereka, ayah suami mereka, anak-anak lelaki mereka, anak-anak lelaki suami mereka, saudara-saudara lelaki mereka, anak-anak saudara lelaki mereka, anak-anak saudara perempuan mereka, wanitawanita Islam, budak- budak yang mereka miliki, pelayanpelayan lelaki yang tidak mempunyai keinginan atau anakanak yang belum mengerti tentang aurat wanita.

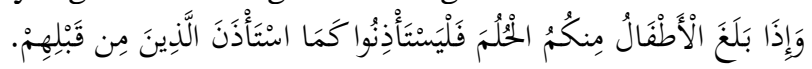

Al-Nūr 24:59

Terjemahan: Apabila anak-anakmu telah sampai umur baligh, maka hendaklah mereka meminta izin, sebagaimana orangorang yang sebelum mereka telah meminta izin.

Digunakan al-tifl dalam ayat pertama dan al-atfäl dalam ayat kedua kerana "menyebut al-tifl dalam bentuk mufrad mempunyai isyarat bahawa kurangnya bahaya kanak-kanak yang tidak mengetahui apa itu aurat dan menyebutnya dalam bentuk jamak mempunyai isyarat bahawa bahaya percampuran mereka dan tidak boleh dipandang mudah untuk mereka melihat aurat". ${ }^{27}$ Justeru, penggunaan mufrad dan jamak di sini tidak menunjukkan bilangannya, tetapi memberi maksud balaghah, iaitu memandang

${ }^{26}$ Muhammad al-Amīn Al-Khuḍrī, al-I 'jāz al-Bayāniyy fì Șiyagh al-Alfāz, 79.

27 Muḥammad al-Amīn Al-Khuḍrī, al-I'jāz al-Bayāniyy fì Șiyagh al-Alfāàz, 5060. 
sesuatu sebagai kecil ketika mufrad dan memandang sesuatu sebagai besar ketika jamak.

Antara maksud balaghah juga ialah kehinaan bagi penggunaan mufrad seperti ayat berikut:

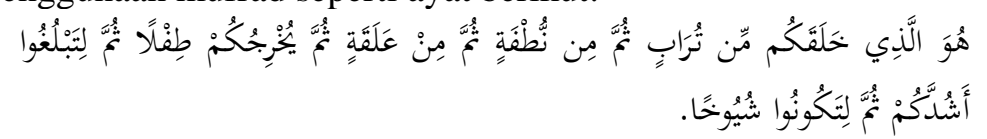

Ghāfir 40:67

Terjemahan: Dialah yang menciptakan kamu dari tanah, kemudian dari setitis air benih, kemudian dari seketul darah beku, kemudian dari seketul daging, kemudian Dia mengeluarkan kamu dalam bentuk kanak-kanak, kemudian kamu sampai ke peringkat umur dewasa, kemudian kamu sampai menjadi tua

Perkataan-perkataan al-turāb, al-nutfah, al-'alaqah disebut dalam bentuk mufrad kerana konteks ayat di sini ialah merendahkan dan menghina orang-orang yang ditujukan ayat ini setelah mereka menolak hakikat bahawa mereka akan dibangkitkan semula selepas kematian mereka. Justeru, bentuk mufradlah yang sesuai digunakan untuk menghina makhluk ciptaan dan mengagungkan Pencipta. ${ }^{28}$ Kesimpulannya bentuk mufrad di sini tidak menunjukkan makna bilangan tunggal, tetapi maksud kehinaan, iaitu maksud balaghahnya. Namun, penulis ingin menambah bahawa makna kehinaan ini turut difahami daripada bentuk nakirah juga, bukannya mufrad sahaja.

Sebaliknya jamak pula digunakan dengan maksud pengagungan, pembesaran, penghormatan, mubālaghah dan seumpamanya. Antara contohnya ialah ayat-ayat yang membicarakan mengenai Allah SWT sendiri dalam konteks melaksanakan perkara besar seperti pemeliharaan al-Quran alKarim dan peristiwa kiamat sebagaimana ayat berikut:

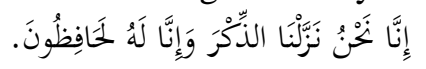

Al-Hijr 15:9

Terjemahan: Sesungguhnya Kamilah yang menurunkan alQuran dan sesungguhnya Kami juga pasti memeliharanya.

${ }^{28}$ Muhammad al-Amīn Al-Khuḍrī, al-I'jāaz al-Bayāniyy fì Șiyagh al-Alfāz,58. 


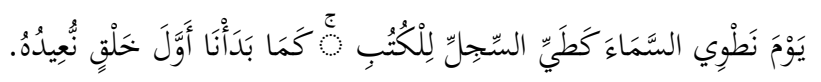

Al-Anbiyā' 21:104

Terjemahan: Pada hari Kami gulungkan langit seperti menggulung lembaran-lembaran kertas. Sebagaimana Kami telah memulakan penciptaan pertama, begitulah Kami akan mengulanginya sebagai satu janji yang pasti.

Ayat tersebut menggunakan ganti nama "Kami" bukan untuk menunjukkan banyak, tetapi menunjukkan keagungan, kebesaran, kehebatan dan seumpamanya.

Maksud yang hampir sama diperhatikan pada ayat 105 surah:

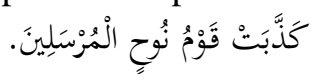

Al-Shu'arā' 26:105

Terjemahan: Kaum Nuh telah mendustakan para Rasul.

Menurut Muhammad al-Amīn, digunakan perkataan almursalin dalam bentuk jamak untuk Nabi Nuh AS sahaja, sedangkan ia adalah mufrad kerana al-Quran hendak "menggambarkan kejelekan jenayah pendustaan Nabi oleh umatnya, maka mereka bukan sahaja mendustakannya sahaja, malah menolak semua risalah langit. Justeru, mereka menanggung dosa mendustakan semua Nabi". ${ }^{29}$ Menurut al-Suyūtī pula bahawa "dengan pendustaan mereka terhadap Nabi Nuh kerana panjangnya masa ia bersama mereka maka seoalah-olah dia adalah ramai Rasul". ${ }^{30}$ maksud jamak di sini ialah membesar dan melebih-lebihkan isu pendustaan Rasul sehingga Rasul itu walaupun seorang sahaja, tetapi dianggap seolah-olah banyak.

Antara contoh yang unik berkaitan maksud balaghah ialah ayat berikut:

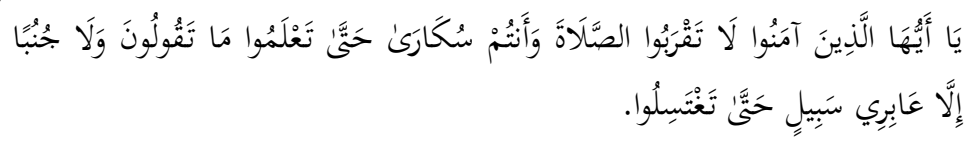

Al-Nisā' 4:43

Terjemahan: Wahai orang-orang yang beriman, janganlah kamu bersolat dalam keadaan kamu mabuk, sehinggalah kamu mengerti apa yang kamu ucapkan. Janganlah (juga

${ }^{29}$ Muḥammad al-Amīn Al-Khuḍrī, al-I 'jāzz al-Bayāniyy fi Șiyagh al-Alfāz, 106.

30 Jalāl al-Dīn al-Suyūṭi wa al-Mahalli, Tafsìr al-Jalālayn (Kaherah: Maṭba'ah 'Īsā al-Bābiyy al-Ḥalabiyy, t.t.), 3:257. 
kamu menghampiri masjid) dalam keadaan kamu berjunub, kecuali sekadar berlalu sahaja, sehinggalah kamu mandi.

Dalam ayat di atas, perkataan sukērā dan 'ābirī sabīl adalah jamak sesuai dengan konteks ayat yang berkaitan dengan orangorang beriman, tetapi perkataan junubā ialah mufrad kerana hendak mengisyaratkan bahawa keadaan berjunub bersifat personal dan hubungan kelamin merupakan perbuatan yang dilakukan secara tertutup. ${ }^{31}$ Kesimpulannya di sini bentuk mufrad tidak menunjukkan bilangannya, sebaliknya menunjukkan makna personal dan tertutup.

Dalam pada itu, terdapat maksud balaghah tertentu tetapi ada kaitan dengan bilangan seperti penggunaan perkataan al-rĭh dan al-riyāh dalam ayat berikut:

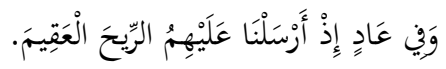

Al-Dhārīyāt 51:41

Terjemahan: (Ingatlah) Kaum Ād ketika Kami hantarkan kepada mereka angin ribut yang tidak mengandungi sebarang kebaikan.

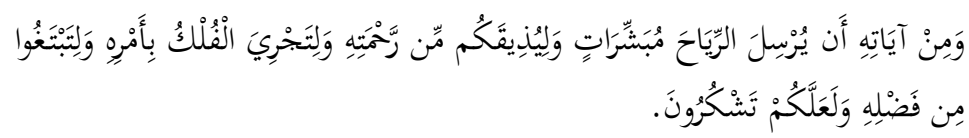

Al-Rūm 30:46

Terjemahan: Antara tanda-tanda kekuasaan-Nya ialah Dia menghantarkan angin sebagai sesuatu yang mengembirakan dan untuk menjadikan kamu merasakan sedikit daripada rahmat-Nya. Begitu juga supaya kapal-kapal dapat belayar dengan perintah-Nya dan juga supaya kamu dapat mencari rezeki dari limpah kurnia-Nya semoga kamu bersyukur.

Apabila dibandingkan antara kedua-dua ayat tadi, didapati bahawa ayat pertama menceritakan mengenai angin yang menyebabkan berlakunya kebinasaan kepada kaum ' $\bar{A} d$ dan perkataan angin digunakan dalam bentuk mufrad, iaitu al-rīh tetapi ayat kedua menceritakan mengenai angin yang mendatangkan kebaikan kepada manusia dan perkataan angin digunakan dalam bentuk jamak iaitu al-riyāh .

Oleh itu, boleh disimpulkan bahawa perkataan al-rịh digunakan dalam bentuk mufrad dalam konteks kebinasaan,

31 Muhammad al-Amīn Al-Khuḍrī, al-I jōàz al-Bayāniyy fì Șiyagh al-Alfāz, 74. 
balasan buruk dan azab, manakala bentuk jamak iaitu al-riyāh digunakan dalam konteks rahmat dan kebaikan. Nampaknya seolah-olah ia tidak menunjukkan bilangan, kerana ia dikaitkan dengan persoalan baik atau buruk. Namun, ulama memberi sebab kenapa digunakan mufrad ketika azab dan jamak ketika rahmat dengan mengaitkannya dengan unsur bilangan. Mereka menyatakan bahawa sebab digunakan mufrad ketika azab adalah kerana ia datang dari satu arah sahaja, tanpa ada yang menghalangnya lalu membinasakan tempat yang dikehendaki. Sebaliknya digunakan bentuk jamak dalam konteks rahmat kerana angin rahmat mempunyai banyak manfaat kepada pelbagai makhluk termasuk binatang dan tumbuhan.

Alasan yang diberikan ini ada logiknya kerana bentuk mufrad juga digunakan dalam konteks rahmat dalam satu ayat lain, iaitu ayat berikut:

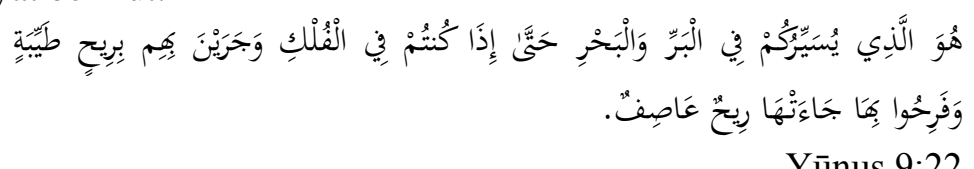

Yūnus 9:22

Terjemahan: Dialah yang menjalankan kamu di daratan dan di lautan sehingga apabila kamu berada di dalam bahtera yang bergerak membawa penumpang-penumpangnya dengan tiupan angin yang baik dan mereka pun gembira dengannya, tiba-tiba datanglah kepadanya angin ribut yang kencang.

Alasan penggunaan bentuk mufrad dalam konteks kebaikan di sini ialah angin akan menjadi rahmat sekiranya ia datang dari satu arah sahaja, bukannya banyak arah. Oleh itu, kapal hanya akan berjalan dengan lancar sekira angin datang dari satu arah sahaja $^{32}$ Kesimpulannya bentuk mufrad dan jamak menunjukkan maksud baik dan buruk tetapi bersumberkan bilangan.

\section{Penutup}

Hasil perbincangan tadi mengenai penggunaan bilangan dalam alQuran al-Karim menunjukkan bahawa terdapat beberapa perkataan tertentu digunakan di dalam al-Quran al-Karim dalam satu bentuk sahaja sama ada mufrad atau jamak yang disebut sebagai metode

32 Al-Zarkashī, Al-Burhān fì 'Ulūm al-Qur'ān, 4:9; Al-Suyūṭi, Al-Itqān fì 'Ulūm al-Qur'ān, 1:194; al-Suyūțī, Mu 'tarak al-Aqrān fì I'jāz al-Qur'ān, 3:596; Ibn al-Qayyīm, Badā' '̄' al-Fawā'id, 1:118. 
iltizam. Hal ini disebabkan oleh sebutannya yang ringan, tiada bentuk nahuannya yang lain dan maksud bilangan berkenaan sama ada satu atau jamak serta maksud balaghah seperti kekerdilan dan kehinaan.

Dalam konteks bukan iltizam, bilangan dalam al-Quran alKarim digunakan bagi menunjukkan bilangan berkenaan secara langsung atau tidak langsung yang dilihat dari aspek dan konteks tertentu yang difokuskan. Namun, kadang-kadang ia tidak menunjukkan bilangan, tetapi memberi maksud balaghah tertentu, seperti sedikit, kecil, besar, kehinaan, keagungan, penghormatan, melebih-lebihkan, baik, buruk dan sebagainya. Disamping itu, ia juga mungkin memberi maksud balaghah tertentu tetapi ada kaitan dengan bilangan dan mengikut kesesuaian konteks ayat tanpa sedikit pun kekurangan dan kelewahan.

\section{Rujukan}

Al-Alūsī, Syihāb al-Dīn al-Sayyid Mạ̣mūd. Rūḥ al-Ma'ānī fì Tafsīr al-Qur'ān wa al-Sab' al-Mathānī. Beirut: Dār Ihyyā' alTurāth al-'Arabiyy, t.t.

Al-Iskāfiyy, Al-Khațīb. Durrah al-Tanzīl wa Ghurrah al-Ta 'wìl fì Bayān al-Āyāt al-Mutashābihāt. Beirut: Dār al-Āfāq al-Jadīdah, 1977.

Al-Khuḍrī Muḥammad al-Amīn. Al-I'jāz al-Bayāniyy fí Șiyagh alAlfāz. Kaherah: Mațba'ah al-Husayn al-Islāmiyyah, 1993.

Al-Maḥalli, Jalāl al-Dīn al-Suyūṭi wa. Tafsīr al-Jalālayn. Kaherah: Maṭba'ah 'İsā al-Bābiyy al-Halabiyy, t.t.

Al-Muț'in̄̄, 'Abd al-'Aẓ̄m Ibrāhīm Muhammad. Khașā'is alTa'bìr al-Qurāniyy wa Simātuhu al-Balāghiyyah. Kaherah: Maktabah Wahbah, 1992.

Al-Sha'rāwī, Muḥammad Mutawallī. 'Alā Mā'idah al-Fikr alIslāmī . t.tp.: Dār al-'Awdah, t.t..

Al-Suhailiyy, Abū al-Qāsim 'Abd al-Rahmān. Natā'ij al-Fikr fì alNaḥw. Riyadh: Dār al-Riyāḍ li al-Nashr wa al-Tawzī', t.t.

Al-Suyūṭī, Jalāl al-Dīn. Al-Itqān fì 'Ulūm al-Qur'ān. Beirut: alMaktabah al-Thaqāfiyyah, 1973.

Al-Suyūṭī, Jalāl al-Dīn. Mu 'tarak al-Aqrān fì I'jāz al-Qur'ān. Beirut: Dār al-Fikr al-'Arabiyy, t.t.

Al-Zarkashī, Muḥammad Ibn 'Abd Allāh. Al-Burhān fì 'Ulūm alQur'ān. Kaherah: Dār Ihyā' al-Kutub al-'Arabiyyah, 1957. 
Fayyūd, 'Abd al-Fattāḥ. Min Balāghah al-Naẓm al-Qur'āniyy. Kaherah: Mațba'ah al-Husayn al-Islāmiyyah, t.t.

Ibn al-Athīr, Diyā' al-Dīn. Al-Mathal al-Sā'ir fì Adāb al-Kātib. Kaherah: Maṭba'ah al-Bābiyy al-Halabiyy, 1990.

Ibn al-Qayyīm, Muḥammad bin Abī Bakr. Al-Tafsìr al-Qayyīm T.tp.: Matba'ah al-Sunnah al-Muhāmmadiyyah, 1949.

Ibn al-Qayyīm, Muḥammad bin Abī Bakr. Badā' '` al-Fawā'id. Beirut: Dār al-Kitāb al-'Arabiyy, t.t.

Ibn Kathīr, Ismā'īl Ibn 'Umar. Tafsīr al-Qur'ān al- 'Azịm. Beirut: Dār Ibn Hazm, 2000. 